Olja Džinkić ${ }^{9}$, student doktorskih studija Univerzitet u Novom Sadu, Filozofski fakultet dr Marijana Kosanović,

Univerzitet u Novom Sadu, Filozofski fakultet
UDC: $37.064 .2: 159.953$

DOI: $10.19090 /$ ps.2018.1.90-101

Primljen: 30.5 .2018 .

Prihvaćen: 30.11.2018.

PREGLEDNI NAUČNI RAD

\title{
IMPLEMENTACIJA KRITIČKOG KONSTRUKTIVIZMA U KURIKULUMU: PRETPOSTAVKE I MOGUĆI ISHODI
}

\author{
Apstrakt
}

Ufokusu ovog rada nalazi se konstruktivistička perspektiva u učenju, koja se usredsređuje na aktivnu, konstruktivnu i socijalnu prirodu učenja. Poseban naglasak usmeren je na implementaciju kritičkog konstruktivizma u kurikulumu, kao i nove zahteve koje postavlja pred nastavnika. Cilj rada odnosi se na sagledavanje osnovnih ideja i elemenata kritičkog konstruktivizma značajnih za efikasno $i$ kvalitetno učenje, te za motivaciju učenika u konstruktivnom procesu učenja. Teorijskom analizom zaključuje se da obrazovni potencijal kritičkog konstruktivizma stavljajući učenika u centar kurikuluma, podstiče samostalnost $i$ odgovornost u procesu sticanja novih znanja. Istovremeno, teorijskom analizom zaključuje se da kritičko-konstruktivistička perspektiva u obrazovanju, kao $i$ nastavnik u novoj ulozi facilitatora mogu imati poseban značaj u razvoju motivacije učenika za efikasno učenje.

Ključne reči: konstruktivizam, kritički konstruktivizam, kurikulum, nastavnik, motivacija za učenje.

\section{UVOD}

Današnje vreme u kojem se događaju brze i učestale promene u društvu, zahteva i promene u obrazovanju. Naime, savremenom načinu života potrebna je savremena nastava koja će prihvatiti i primenjivati one koncepte koji će osigurati razvoj svakog pojedinca i na taj način omogućiti da uspešno odgovara tim promenama. Današnji učenici su često nezainteresovani za nastavne sadržaje i aktivnosti. Takođe, nezaobilazna je činjenica da

\footnotetext{
"olja.dzinkic@gmail.com
} 
učenici sve teže uspostavljaju smislenu vezu između onoga što ih uče u školi i svakodnevnog života, kao i da učenici imaju poteškoće u primeni znanja pri rešavanju realnih životnih problema. To je samo jedan od razloga zbog kojih konstruktivistička teorija izaziva sve veću pažnju naučnika u području obrazovanja. Dalje u radu biće predstavljeni upravo konstruktivistički pristupi učenju i poučavanju, čiji se programski zahtev tiče promene naglaska u nastavnom radu - sa poučavanja na učenje. Odnosno, didaktička implikacija konstruktivizma glasi - način na koji učenici uče važnije je od toga na koji način nastavnik poučava.

U poslednjih dvadesetak godina u pedagogiji i psihologiji konstruktivizam je postao jedan od ključnih pojmova kada je reč o reformi obrazovanja, te predstavlja najnoviji model u izradi kurikuluma (Ljubojević, 2012). Iz konstruktivističke teorije obrazovanja u radu izdvajamo kritički konstruktivizam, koji se odskora pojavljuje u pedagoškoj literaturi. S obzirom da predstavlja novinu u našoj obrazovnoj praksi, cilj ovog rada je da predstavi osnovne principe i pretpostavke kritičkog konstruktivizma kao teorijske osnove za pristup učenju i poučavanju, i načinu izrade kurikuluma. U radu se razmatraju elementi kritičkokonstruktivističkog kurikuluma kao podsticajnog i motivacionog faktora za efikasno učenje učenika. Dalje u radu se predstavljaju novi zahtevi i uloga nastavnika u takvom kurikulumu, te način rada koji motiviše učenike u izgradnji i konstruisanju svojih znanja.

\section{OSNOVNE KARAKTERISTIKE KONSTRUKTIVIZMA U OBRAZOVANJU}

Konstruktivizam kao teorija učenja svim nastavnicima približava i objašnjava proces učenja, uključujući učenje na individualnom nivou, kao i učenje u društvenom kontekstu. Pojedini autori (Gatt \& Vella, 2003) smatraju da je prednost konstruktivizma u njegovoj jednostavnoj primeni u praksi unutar učionice, stoga je prihvaćen i usvojen širom sveta. Osnovi cilj teorije konstruktivizma $\mathrm{u}$ nastavi odnosi se na formiranje nastavnog plana koji podstiče efikasno učenje. Mnogi naučnici iz različitih disciplina su doprineli razvoju konstruktivizma. Međutim konstruktivističke obrazovne ideje uglavnom su proizašle iz rada Pijažea (Jean Piaget) i Vigotskog (Lev Vygotsky) (Bentley, 2003; Palmer, 2005). Unutar konstruktivističke teorije razvijeni su različiti pristupi i interpretacije, a u literaturi se najčešće spominju dva pravca u konstruktivizmu: "socijalni” konstruktivizam i “individualni” konstruktivizam (Jukić, 2013; Palmer, 2005). Individualni konstruktivizam akcenat stavlja na intrapsihičke kognitivne procese pomoću kojih se konstruiše stvarnost. Začeci ove forme konstruktivizma vezuju se za teoriju kognitivnog razvoja Pijažea (Piaget) (Milutinović, 2011). Pijažeovo shvatanje 
kognitivnog razvoja ima veliki uticaj na učenje i nastavu i predstavlja osnovu za razvoj učenja putem otkrića i heurističkog modela nastave (Ljubojević, 2012). Socijalni konstruktivizam se oslanja na ulogu društva u konstruisanju i kreiranju znanja. Smatra se da su koreni socijalnog konstruktivizma proizašli iz sociokulturne teorije Vigotskog (Milutinović, 2011), koji za kognitivni razvoj svake individue naglašava uticaj jezika i kulture (Jukić, 2013). A njihova značajna uloga ogleda se u mogućnosti da "kroz jezik i kulturu ljudi stiču iskustvo, komuniciraju, opažaju i razumeju svet oko sebe. Konstruktivističko shvatanje individue kao subjekta vlastitog razvoja rezultiralo je pojavom "samoaktivnog subjekta" u konceptu "samosocijalizacije" u okviru socijalnog konstruktivizma" (Jukić, 2013: 243). U novije vreme za pomenute koncepcije konstruktivizma Pijažea i Vigotskog vezuju se pojedine kritike. Tako se u razmatranju novih ideja javlja kritički konstruktivizam, koji pridaje značajnu ulogu socijalnog i kulturnog okruženja u konstruisanju znanja (Milutinović, 2015).

Danas konstruktivizam predstavlja značajnu filozofiju obrazovanja. Uprkos razlikama u njegovom tumačenju, zajednička osnova različitih interpretacija konstruktivizma u domenu obrazovanja jeste tvrdnja da učenici nisu pasivni primaoci znanja, i da su aktivno uključeni $u$ njegovoj izgradnji (Gatt \& Vella, 2003; Milutinović, 2016). Ovaka aktivna uloga stavlja učenika u središte nastave u konstruktivističkoj obrazovnoj sredini (Ebrahimi, 2013). Dakle, konstruktivizam u oblasti obrazovanja predstavlja alternativu transmisionom modelu obrazovanja. Transmisioni model obrazovanja podrazumeva okruženje učenja orijentisanog na nastvnika kao i na sadržaje poučavanja. Učenik ima pasivnu ulogu u nastavnom procesu, i ovim modelom dominira mehaničko memorisanje i pamćenje. Suprotno transmisionom modelu, konstruktivistički model obrazovanja podrazumeva koncept obrazovanja usmerenog na učenika, o čemu će biti reči u nastavku rada (Milutinović, 2016).

Prema shvatanjima konstruktivizma svaki pojedinac može da konstruiše i kreira svoje znanje u različitim situacijama i okolnostima. Drugim rečima, učenici ne dobijaju znanje u gotovom obliku od nastavnika, već aktivno izgrađuju znanje. Stoga se osnovne ideje konstruktivizma i te kako podržavaju i primenjuju u nastavi sa ciljem povećanja efikasnosti procesa učenja (Gatt \& Vella, 2003). Prema konstruktivističkoj paradigmi Mušanović (2000) navodi da učenje zavisi od ukupnog prethodnog znanja, uključuje stvaranje ideja pre nego gomilanje podataka, a tokom učenja nove ideje se razvijaju kroz proces adaptacije i promene starih ideja pri čemu se učenje sa smislom događa transformacijom starih ideja i stvaranjem novih tvrdnji i konstatacija. U kontekstu navedenog znanje je rezultat aktivnog i svesnog saznavanja individue, a proces sticanja znanja predstavlja se kao proces koji čini da iskustva osobe 
dobiju smisao i tok. Dalje autor objašnjava da se konstruktivistička teorija zasniva na verovanju prema kojem se proces učenja odvija na temeljima lične konstrukcije i rekonstrukcije znanja, a ono u stvari nastaje učeničkim interakcijama sa okruženjem u sociokulturnom kontekstu. Prema konstruktivističkom shvatanju poučavanje podrazumeva kreiranje situacija u kojima učenici aktivno sarađuju i učestvuju i u kojima stvaraju svoje individualne konstrukcije. Stoga obrazovna sredina mora podsticajno da deluje na intelektualne aktivnosti učenika i da obezbeđuje dvosmernu komunikaciju (Mušanović, 2000). Na osnovu do sad napisanog zaključuje se, učenje i poučavanje treba da se realizuju u podsticajnoj sredini. U konstruktivističkoj sredini za učenje, celokupan nastavni sadržaj, materijali koje u nastavi koriste učenici, kao i njihov tempo učenja i napredovanja temelje se na sposobnostima i interesima svakog pojedinog učenika (Ebrahimi, 2013). U celini posmatrano, konstruktivistička sredina za učenje podstiče učenike da budu odgovorni za sopstveno učenje, omogućava im da napreduju svojim tempom, a nastavne sadržaje povezuje sa svakodnevnim životnim pitanjima što otvara put za smisleno i efikasnije učenje.

\section{Kritički konstruktivizam u obrazovanju}

Kritički konstruktivizam podrazumeva teorijski stav u obrazovanju koji doprinosi i približava se demokratskom društvu. Takav pogled na obrazovanje menja funkciju škole, te od pripreme za dobre rezultate na testovima, škola ima ulogu da razvija ličnu i društvenu svest učenika, omogući im da postanu kreatori sopstvenog znanja i da se izgrade tokom svog života (Bentley, 2003). Dakle u fokusu kritičko-konstruktivističke nastave je društvena svest i demokratsko drušvo, razvijanje mašte i podsticanje učenika na razmišljanje (Bentley, Fleury \& Garrison, 2007).

Razmatrajuću kritičko-konstruktivističku epistemologiju Gari Simpson (Gary Simpson) (2004) razvio je šest pedagoških karakteristika:

1. Procenjivanje već stečenog znanja i razumevanja učenika.

2. Sledeća pedagoška karakteristika ukazuje na važnu ulogu nastavnika kao posrednika i pokretača namernih aktivnosti u procesu učenju učenika.

3. Društvena svest, koja je u osnovi kritičkog konstruktivizma, razvija se uspostavljanjem društvenih situacija u kojima učenici diskutuju, postavljaju pitanja i formiraju nova iskustva na osnovu onoga što već znaju.

4. U okviru ove epistemologije ističe se važnost različitih mogućnosti za učenike da predstavljaju svoje znanje i sposobnosti. 
5. Takođe značajno jeste konstantno praćenje aktivnosti učenika da bi prevazišli prepreke i dostigli dubinu razumevanja.

6. Važna pedagoška karakteristika kritičkog konstruktivizma jeste pogled na učenika kao jedinstvenog pojedinca.

Današnje škole, tradicionalnim načinom rada, prenose učenicima znanje koje ne uspostavlja smislenu vezu sa svakodnevnim životnim situacijama i problemima. Na ovaj način preneseno znanje navodi učenika na pomisao da je znanje vlasništvo predavača, a ne društveni produkt. S druge strane, ako znanje posmatramo u svetlu kritičkog konstruktivizma ono dobija socijalnu, političku i kulturnu osnovu u nastavi. Usvajanje znanja na ovoj osnovi je kooperativno kroz interakciju, uz primenu prethodno stečenih znanja i iskustava (Bentley, Fleury \& Garrison, 2007). U tom smislu, "priznavanjem lične i društvene prirode izgradnje znanja, i negiranjem mogućnosti prenošenja objektivnog znanja iz jednog u drugi um, pristup inherentno promoviše ravnopravniju raspodelu autoriteta $u$ učionici i višim nivoima motivacije i aktivnog učešća" (Ebrahimi, 2013: 166).

\section{Implementacija kritičkog konstruktivizma u kurikulumu: motivacija za učenje kao mogući ishod}

Napomenuli smo da kritički konstruktivizam pruža drugačiji pogled na procese učenja i poučavanja, kao i na izradu kurikuluma u odnosu na već postojeće, tradicionalne modele rada, te u nastavku sledi podrobnije objašnjenje. Naime, proces poučavanja zasnovan na idejama kritičkog konstruktivizma podrazumeva organizovanje različitih situacija u učionici, a ne prenošenje znanja u gotovom obliku (Driver \& Oldham, 1986). U ovom kontekstu, promene se reflektuju i na ulogu učenika koji izlazi iz statične pozicije i postaje aktivan učesnik u izgradnji sopstvenog znanja. Dakle, kritičko-konstruktivistička koncepcija obrazovanja ističe značaj aktivnog sticanja znanja (Gatt \& Vella, 2003; Dindar, 2016; Milutinović, 2016). Takva promena odnosa prema znanju zahteva primenu raznovrsnih nastavnih metoda, oblika rada, kao i primenu različitih aktivnosi poput pisanja, diskusije i interakcije u grupama, projekata i simulacije (Milutinović, 2015). Kako dalje autor navodi ove aktivnosti formiraju kritički stav prema znanju i doprinose izgradnji nastavnog kurikuluma. U okvire kritičkog konstruktivizma spada nastava usmerena na učenika, poput istraživačke i problemske nastave, čiji je ishod pripremljenost učenika za aktivnu ulogu građanina i učestale promene u svetu. Postupci traganja i otkrivanja motivišu i podstiču učenike, bude pažnju i navode ih da misle o nastavnom sadržaju i van škole. Kada se dođe do 
rešenja, javlja se osećanje kompetencije i interesa, a time i jače motivacije za dalje učenje (Rakić, 1970). U svojim istraživanjima Gabrijela Viver (Gabriela Weaver) (Prema: Grandić i Gajić, 1998) je dokazala da praktične aktivnosti pokreću motivaciju učenika i stvaraju interesovanje za učenje. Drugim rečima, nastavni sadržaji koji ne pružaju mogućnost aktivnog delovanja učenika i različitih oblika učenja ne mogu da podstaknu motivaciju za učenje. U tom smislu, može se zaključiti da kritičko-konstruktivistički kurikulum zasnovan na angažovanosti, saradnji i raznovrsnim oblicima aktivnog delovanja, razvija motivaciju učenika za učenje.

Za izradu kritičko-konstruktivističkog kurikuluma ne postoji tačno određen recept, već se primenjuju različite strategije i metode koje pomažu učenicima u kreiranju znanja, a neke od njih kako navode autori (Bentley, Fleury \& Garrison, 2007: 8) su: "skale, modeliranje, podučavanje, ispitivanje, vođenje i savetovanje. Naime, u osnovi kritičko-konstruktivističkog kurikuluma su procesi koji podstiču i ohrabruju učenike da stvaraju i razvijaju svoje misli, ideje i stavove". Takav nastavni plan i program neguje rast i razvoj uma, stvara uslove za saradnju i timski rad, što dovodi do značajnog napredovanja u procesu učenja učenika (Lunenburg, 2011). U tom pogledu, kritičko-konstruktivistička sredina za učenje deluje motivaciono na učenike u izgradnji i kreiranju svojih saznanja. Istraživanje sprovedeno $u$ Hongkongu, koje je realizovao Vong (Wong Wai Line) sa saradnicima (Prema: Milutinović, 2015) na uzorku učenika od šesnaest do devetnaest godina, pokazuje pozitivan stav prema nastavi koja nastavni sadržaj povezuje sa svakodnevnim životom i vanškolskim saznanjima učenika. Takođe, dobijeni su pozitivni rezultati prema nastavi koja uključuje učenike u planiranju nastavnih aktivnosti, uvažava i prihvata njihove stavove, i dodeljuje im aktivnu ulogu u sticanju i razmeni novih znanja. Dobijeni podaci pokazuju značajnu povezanost između kritičko-konstruktivističke sredine za učenje i povećanja unutrašnje motivacije učenika za nastavne sadržaje i razvijanja osećaja samoefikasnosti.

Motivacija predstavlja potrebu i preduslov za učenje u kritičko-konstruktivističkoj sredini (Palmer, 2005). Ako se fokusiramo na razmatranje ove izjave uviđamo niz primera i činjenica koje je potvrđuju. Oslanjajući se na ovu tvrdnju, može se još primetiti da zadatak o kojem se vodi računa u kritičko-konstruktivističkom kurikulumu, i istovremeno povećava motivaciju učenika za učenje jeste povezanost nastavnih sadržaja sa svetskim problemima i svakodnevnim životom (Dindar, 2016; Topolovčan, 2016). Kada učenicima nedostaju konteksti u koje će smestiti informaciju i bogato povezane mreže ideja koje bi pojačale njenu smislenost, oni su primorani da se oslanjaju na mehaničko pamćenje umesto da koriste efikasnije strategije pamćenja i učenja. Učenici pamte što više do momenta testiranja, ali 
posle toga zaboravljaju najveći deo informacija, odnosno internog znanja koje ne mogu da koriste u situacijama relevantne primene. Da bi se učenicima omogućilo da konstruišu smisleno znanje kome mogu pristupiti i koje mogu koristiti u životu potrebno je odstupati od širokog pokrivanja sadržaja kako bi bilo dovoljno vremena da se najvažniji sadržaji dublje razvijaju. Takođe, nastavni sadržaj treba da bude predstavljen u vidu mreža povezanih informacija $s$ fokusom na objašnjavanje važnih ideja i njihovih međusobnih veza (Brofi, 2015). Uzeći u obzir do sada napisano, zaključuje se da podizanjem kvaliteta nastavnog rada povećava se mogućnost za podsticanje unutrašnje motivacije kod učenika. Učenici ne pokazuju negativan odnos prema učenju uopšte već samo prema školskom učenju koje se karakteriše prinudom i odbojnošću i koje ne angažuje potencijale učenika (Grandić i Gajić, 1998).

\section{Uloga nastavnika - od predavača do facilitatora}

Ako se u obrazovnom procesu krene od interesovanja i aktivnosti učenika menja se i uloga nastavnika. Nastavnik ne prenosi informacije koje su zapisane prema programu, a koje učenici treba da usvoje, već on mora dozvoliti da uče ono za šta pokazuju interesovanje. Nastavnik obezbeđuje situacije i uslove kroz koje učenici uče iz vlastitog iskustva (Milutinović, 2008). Dakle, nova uloga nastavnika posebno dolazi do izražaja u kreiranju sredine za učenje, koja podstiče razvoj kognitivnih sposobnosti učenika, podstiče motivaciju za učenje, omogućava uspešan tok učenja, unapređuje samostalni rad, ali i saradnju i komunikaciju (Rodek, 2011). Drugačije rečeno, "kritički konstruktivizam proširuje profesionalne uloge nastavnika, podržavajući koncepciju nastavnika istraživača koja pretpostavlja kompetencije za istraživanje učenika, društvene pozadine školstva, i principa na osnovu kojih se sabira, organizuje i kontroliše školsko znanje" (Milutinović, 2015: 445-446). Nova uloga nastavnika podrazumeva ohrabrivanje učenika da razmišljaju, razlažu problem na različite načine, te iznose svoje misli i ideje u učionici. U novoj ulozi od nastavnika se očekuje da uključi učenike u proces učenja, vodi računa o motivaciji i podstiče učenike na postavljanje problema (Gatt \& Vella, 2003). Takođe zahtevi koje se postavljaju pred nastavnika jesu otvorenost uma i spremnost da sasluša šta učenici imaju da kažu i da prepozna razlike u njihovim potrebama u procesu učenja i poučavanja. Od velikog je značaja da nastavnik podrži nastojanja učenika da što jasnije artikulišu vlastite ideje. Takođe da kreira obrazovni kontekst u kojem će svaki učenik imati priliku da se upozna s mišljenjem drugih i da zajedno s njima pregovara o alternativnim značenjima. Na taj način učenik postaje aktivan 
učesnik u procesu učenja i poučavanja, a ne pasivni posmatrač ili primalac znanja (Milutinović, 2016).

Džeklin Grenon Bruks i Martin Bruks (Brooks \& Brooks, 2005) opisuju postupke i načine ponašanja karakteristične za konstruktivističkog nastavnika u učionici. Naime, nastavnik zanemaruje svoju ulogu predavača i prihvata inicijativu učenika da traži smislene veze, formuliše pitanja, analizira i daje odgovore. Od nastavnika se očekuje da proces učenja vezuje za realne i postojeće probleme. Ova koncepcija podrazumeva uključivanje učenika u dijalog, ohrabrivanje da postavljaju pitanja jedni drugima, kao i stvaranje uslova da iznose svoje ideje i kreiraju nova shvatanja (Brooks \& Brooks, 2005). Da bi nastavnik mogao uspešno da vodi učenike kroz proces sticanja znanja, postavlja prava pitanja, predlaže i navodi učenike na sledeći korak $u$ istraživanju, mora posedovati zavidno znanje iz svoje predmetne oblasti (Simpson, 2004). Konstruktivistički nastavnici neguju i podstiču radoznalost učenika kroz interakciju sa raznovrsnim materijalima i uvođenjem koncepta otkrića u podsticajnoj sredini. U kritičko-konstruktivističkoj sredini učenje učenika se ocenjuje u kontekstu svakodnevne angažovanosti i učenja (Brooks \& Brooks, 2005). Autori dalje objašnjavaju da se ocena ne posmatra izolovano od uobičajenih aktivnosti učenika u učionici, te se vrednuje celokupno učešće u nastavi. Odnosno, evaluacija učenja se sprovodi posmatranjem napretka učenika u saradničkim aktivnostima, što podrazumeva primenu procenjivanja putem vođenja beležaka, prikupljanja učeničkih portfolia, korišćenja nestandardizovanih testova, esejskih pitanja i praktičnih zadataka (Milutinović, 2011).

$\mathrm{Na}$ osnovu do sada napisanog može se zaključiti da kritičko-konstruktivistički pristup nastavi postavlja nove zahteve za nastavnika. Ovakav pristup odbacuje tradicionalanu ulogu predavača i karakteriše nastavnika kao facilitatora znanja. Hand i Vance (Prema: Gatt \& Vella, 2003: 14-15) objašnjavaju da "facilitator stvara prilike da drugi istražuju, pomaže više nego što govori, podstiče i ohrabruje da se pronađu rešenja za postojeće probleme”. Stoga, facilitacija se može posmatrati kao odnos između dve ili više osoba, koje su motivisane da uče i da doprinose procesu učenja drugih. Ovakav odnos zagovara partnerstvo i saradnju između nastavnika i učenika, a osnovna uloga nastavnika je da obezbedi povoljnu sredinu i efikasne aktivnosti koje razvijaju nezavisnost učenika (Kostović, 2005). Takođe važna uloga nastavnika podrazumeva verovanje u veštine i sposobnosti učenika, pohvale za njihove uspehe, kao i pružanje osećaja poverenja i empatije. Dakle, facilitacija se zasniva na kvalitetu odnosa, te u učionici treba ostvariti direktnu i otvorenu komunikaciju (Đermanov, Vukičević i Kosanović, 2012). Drugim rečima, pored odgovornosti nastavnika u realizovanju nastavnih aktivnosti, od njega zavisi kvalitet odnosa prema učenicima. Saradnički odnos između 
nastavnika i učenika doprinose socioemocionalnoj klimi u učionici, što značajno utiče na razvoj motivacije za učenje (Grandić i Gajić, 1998; Simpson, 2004).

U celini posmatrano, prihvatanjem kritičko-konstruktivističkog pristupa učenja u kreiranju kurikuluma za nastavnika predstavlja proces u kojem njegova uloga dobija nova značenja. Nastavnik postaje voditelj, motivator, saradnik, su-istraživač, facilitor stvaranja ideja, stavova, mišljenja, vrednosti i dr. Na osnovu do sad napisanog, može se zaključiti da iako kritičko-konstruktivističke teorije u centar nastave stavljaju učenika, uloga nastavnika je veoma bitna. Od načina rada nastavnika, od toga koliko je spreman za saradnju i otvoren za primenu različitih metoda rada zavisi koliko će učenici biti uključeni u proces učenja, koliko će biti u ulozi konstruktora sopstvenih znanja i da li će biti motivisani da preuzmu tu ulogu.

\section{Zaključna razmatranja}

U razmatranju kritičko-konstruktivističkog kurikuluma kao motivacionog faktora za učenje, nailazimo na snažnu teorijsku podršku koja potvrđuje naše pretpostavke. Uistinu ovakav kurikulum nudi stvarno obećanje za veću motivisanost i angažovanost u nastavi svih učenika, što se ujedno odražava na veća postignuća i efikasnije učenje. Nakon našeg teorijskog prikaza, zaključuje se da ovakvo učenje razvija stvaralačke sposobnosti i maštu kod učenika, da su potpuno angažovani i aktivni u procesu svog razvoja, a nastavnik je pokretač, a ne poučivač na tom putu. Kao što se može videti na osnovu teorijske analize nastavnik ima veoma značajnu ulogu u realizaciji kurikuluma, stvaranju povolje socioemocionalne klime i podsticajne sredine za učenje. Od njega zavisi da li će nastava biti stereotipna ili inventivna i stvaralačka, ali i kvalitet njegovih odnosa prema učenicima, kao i odnos između samih učenika. Podizanjem kvaliteta nastavnog rada povećava se mogućnost za podsticanje unutrašnje motivacije kod učenika. Uzimajući u obzir sve rečeno, može se zaključiti da kritičko-konstruktivistički pristup nastavi postavlja nove zahteve za nastavnika, te odbacuje tradicionalanu ulogu predavača i karakteriše nastavnika kao facilitatora znanja. Facilitacija (Kostović, 2005) se posmatra kao odnos između dve ili više osoba, koje su motivisane da uče i da doprinose procesu učenja drugih. Ovakav odnos zagovara partnerstvo i saradnju između nastavnika i učenika, a osnovna uloga nastavnika je da obezbedi povoljnu sredinu i efikasne aktivnosti koje razvijaju nezavisnost učenika.

Na osnovu do sada napisanog, tvrdnju da motivacija predstavlja potrebu i preduslov za učenje u kritičko-konstrukivističkoj sredini (Palmer, 2005) označavamo kao tačnu iz više razloga. Naime, aktivnosti u okviru kritičko-konstruktivističkog kurikuluma najviše su povezane sa 
stvarnim životom, potiču iz dubokih interesa i potreba učenika, a dobro je poznato da radoznalost i zainteresovanost predstavljaju značajne pokretačke snage. Dalje, korisnost ovakvog načina učenja se vidi i u usmeravanju i zadržavanju pažnje učenika na ono čime se bavi, što nam govori da učenje kroz aktivnost pokreće unutrašnju motivaciju. Dakle, angažovanost učenika, saradnja i svi oblici aktivnog delovanja podstiču motivaciju, a kao što se može videti na prethodnim stranicama, ovakav način rada nalazi se u osnovi kritičkokonstruktivističkog kurikuluma.

Olja Džinkić, Novi Sad, Serbia

Marijana Kosanović, nvi Sad, Serbia

\title{
IMPLEMENTATION OF CRITICAL CONSTRUCTIVISM IN THE CURRICULUM: ASSUMPTIONS AND POSSIBLE OUTCOME
}

\begin{abstract}
In the focus of these works there is a constructivist perspective in learning, which focuses on the active, constructive and social nature of learning. A special emphasis is oriented on the implementation of critical constructivism in the curriculum, as well as the new demands placed on teachers. The aim of the paper is look to the basic ideas and elements of critical constructivism important for effective and quality learning, as well as for motivating students in a constructive learning process. Theoretical analysis concludes that the educational potential of critical constructivism puts students at the center of the curriculum, encourages autonomy and responsibility in the process of acquiring new knowledge. At the same time, the theoretical analysis concludes that the critical-constructivist perspective in education, as well as the teacher in the new role of the facilitator, can have special significance in developing students' motivation for effective learning.
\end{abstract}

Key words: constructivism, critical constructivism, curriculum, teacher, motivation for

\section{Literatura}

Bentley, L. M. (2003). Introducing Critical Constructivism: Critical Consciousness Through A Critical Constructivist Pedagogy, Mexico City, American Educational Studies Association.

Bentley, L. M., Fleury, C. S., \& Garrison, J. (2007). "Critical Constructivism for Teaching and Learning in a Democratic Society" The Journal of Thought, 42(3-4), 9-22. 
Brooks, J. G., \& Brooks, M. (2005). In Search of Understanding: The Case for Constructivist Classrooms, Alexandria, Association for Supervision and Curriculum Development.

Brofi, Dž. (2015). Kako motivisati učenike da uče, Beograd, Clio.

Gatt, S., \& Vella, Y. (2003). Constructivist Teaching in Primary School: Examples in Social Studies, Science, Mathematics, Design and Technology and ICT, Malta, Agenda Publishers.

Grandić, R., \& Gajić, O. (1998). Teorije intelektualnog vaspitanja, Novi Sad, Savez pedagoških društava Vojvodine.

Dindar, C. A. (2016). "Student Motivation in Constructivist Learning Environment" Eurasia Journal of Mathematics, Science \& Technology Education, 12(2), 233-247.

Driver, R., \& Oldham, V. (1986). “A Constructivist Approach to Curriculum Development in Science" Studies in Science Education, 13(1), 105-122.

Đermanov. J., Vukičević, J., \& Kosanović, M. (2012). Facilitacija - uloga nastavnika koncepciji dožvotnog učenja. U Zbornik radova Kvalitet obrazovnog sistema Srbije u Evropskoj perspektivi (91-101), Novi Sad, Filozofski fakultet Univerzitet u Novom Sadu.

Ebrahimi, N. A. (2013). "Constructivist Translation Classroom Enviroment Survey (CTLES): Development, Validation and Application" Translation \& Interpreting, $5(2), 163-186$.

Jukić, R. (2013). “Konstruktivizam kao poveznica poučavanja sadržaja prirodoznanstvenih i društvenih predmeta" Pedagogijska istraživanja, 10(2), 241-263.

Kostović, S. (2005). Vaspitni stil nastavnika, Novi Sad, Savez pedagoških društava Vojvodine.

Lunenburg, C. F. (2011). "Critical Thinking and Constructivism: Techniques for Improving Student Achievement" National Forum of Teacher Education Journal, 21(3), 1-9.

Ljubojević, D. (2012). Konstruktivistička paradigma kao nova teorijska osnova za usvajanje stranih jezika. U Zbornik radova sa međunarodnog naučnog skupa Filološka istraživanja danas (96-113), Beograd, Filološki fakultet u Beogradu.

Milutinović, J. (2008). Ciljevi obrazovanja i učenja u svetlu dominantnih teorija vaspitanja 20.veka, Novi Sad, Savez pedagoških društava Vojvodine.

Milutinović, J. (2011). Socijalni konstruktivizam u oblasti obrazovanja i učenja. U Zbornik Instituta za pedagoška istraživanja (177-194), Novi Sad, Filozofski fakultet. 
Milutinović, J. (2015). “Kritički konstruktivizam - koncepcija i mogućnosti u oblasti obrazovanja" Nastava i vaspitanje, 64(3), 437-451.

Milutinović, J. (2016). Socijalni i kritički konstruktivizam u obrazovanju, Novi Sad, Filozofski fakultet.

Mušanović, M. (2000). Konstruktivistička teorija i obrazovni proces. U Didaktični in metodični vidiki nadaljnega razvoja izobraženja (28-35), Maribor, Univerza v Mariboru, Pedagoška fakulteta Mariboru.

Palmer, D. (2005). "A Motivational View of Constructivist - informed Teaching" International Journal of Science Education, 27(15), 1853-1881.

Rakić, B. (1970). Motivacija i školsko učenje, Sarajevo, Zavod za izdavanje udžbenika.

Rodek, S. (2011). "Novi mediji i nova kultura učenja” Napredak, 152(1), 9-28.

Simpson, G. (2004). "Critical constructivism, Neo-Relativism, and the Place of Values in Science Education” The Science Education Review, 3(1), 23-28.

Topolovčan, T. (2016). “Art-Based Research of Constructivist Teaching” Croatian Journal of Education, 18(4), 1141-1172.

Weaver, G. C. (1998). "Strategies in K-12 science instruction to promote conceptual change" Science Education, 82(4), 455-472. 